\title{
CHEMICAL SORTING EFFECT AT THE BASE OF AN ALPINE GLACIER
}

\author{
By R. A. Souchez and R. D. Lorrain \\ (Laboratoire de Géomorphologie, Faculté des Sciences, Université Libre de Bruxelles, \\ Avenue F. D. Roosevelt, 50, B ro5o Bruxelles, Belgium)
}

\begin{abstract}
A frozen mud layer plastered at the base of the Glacier d'Argentière in the Western Alps acts as an ion-exchange membrane for the interstitial water passing through it, causing electrolyte filtration and relative retardation of cations. This interstitial water, which is forced under a pressure gradient of about $3 \mathrm{bar}^{-1}$, refreezes in the form of ice accretions.

A comparison of the chemical composition of these ice accretions and water held at their surface (corresponding to the situation after the forcing) and the water in contact with the mud layer (corresponding to the situation before the forcing) shows a desalinating effect, a monovalent-divalent cation species separation, and a sorting effect between the alkalies as well as between the alkaline-earths. This phenomenon has to be taken into account in the study of the chemical composition of stratified ice containing interbedded mud layers which occurs in the basal part of several glaciers.
\end{abstract}

RÉsumé. Sélection chimique à la base d'un glacier alpin. Une couche de boue tapissant la base du glacier d'Argentière (Alpes occidentales) se comporte comme une membrane échangeuse d'ions vis-à-vis de l'eau interstitielle qui la traverse; elle provoque une filtration électrolytique différentielle. Cette eau interstitielle traverse la couche de boue sous un gradient de pression d'environ $3 \mathrm{bar} \mathrm{cm}^{-1}$; après quoi, elle regèle sous forme de copeaux et de spicules de glace.

Une comparaison de la composition chimique de ces glaces de regel et de l'eau retenue à leur surface (situation après passage) avec l'eau en contact avec la couche de boue (situation avant passage) montre une diminution de la concentration des cations majeurs, une filtration sélective non seulement des bivalents par rapport aux monovalents mais encore au sein même des alcalins aussi bien que des alcalino-terreux. Ce phénomène doit être pris en considération dans l'étude de la composition chimique des glaces profondes contenant des lits de boue interstratifiés.

Zusammenfassung. Ein chemischer Sortiereffekt an der Basis eines alpinen Gletschers. Eine gefrorene Schlammschicht, die an der Basis des Glacier d'Argentière in den Westalpen festsitzt, wirkt wie eine Ionen-Austauschmembrane auf das sie durchdringende Porenwasser, wobei elektrolytische Filterung und relative Verzögerung der Kationen verursacht werden. Dieses Porenwasser, auf das ein Druckgradient von etwa $3 \mathrm{bar}^{\mathrm{cm}} \mathrm{m}^{-1}$ einwirkt, regeliert in Form von aufwachsendem Eis.

Ein Vergleich der chemischen Zusammensetzung dieser Eisaufwüchse und des an ihrer Oberfläche gehaltenen Wassers (entsprechend dem Zustand nach der Druckeinwirkung) mit der des Wassers, das mit der Schlammschicht in Berührung ist (entsprechend dem Zustand vor der Druckeinwirkung), zeigt folgendes auf: einen Entsalzungseffekt, eine Trennung in monovalente und divalente Kationenarten und einen Sortiereffekt sowohl zwischen den Alkalien wie zwischen den alkalischen Erden. Dieser Erscheinung muss beim Studium der chemischen Zusammensetzung von geschichtetem Eis, in das Schlammschichten eingebettet sind, so wie es an der Basis von mehreren Gletschern vorkommt, Rechnung getragen werden.

\section{INTRODUCTION}

The base of an alpine glacier is sometimes plastered with a frozen mud layer. Such a mud layer has been observed at the ceiling of an enclosed natural subglacial cavity beneath the Glacier d'Argentière in the Western Alps (Fig. I). Its thickness ranges from 2 to $3 \mathrm{~cm}$. A large pressure gradient exists across this mud layer: interstitial water in the glacier at its upper surface is under the hydrostatic pressure of about $90 \mathrm{~m}$ of ice and, at its lower surface, under the atmospheric pressure of the cavity. This interstitial water is thus forced through the mud layer under a pressure gradient of about $3 \mathrm{bar} \mathrm{cm}^{-1}$ and refreezes in the form of ice accretions hanging at the ceiling (Souchez and others, 1973). This refreezing is the consequence of the pressure dependence of the freezing point.

\section{SAMPLE DESGRIPTION AND TREATMENT}

With the aid of a recorder-equipped atomic absorption spectrophotometer (Perkin Elmer 303) chemical analyses for $\mathrm{Na}, \mathrm{K}, \mathrm{Ca}$, and $\mathrm{Mg}$ were performed on: 


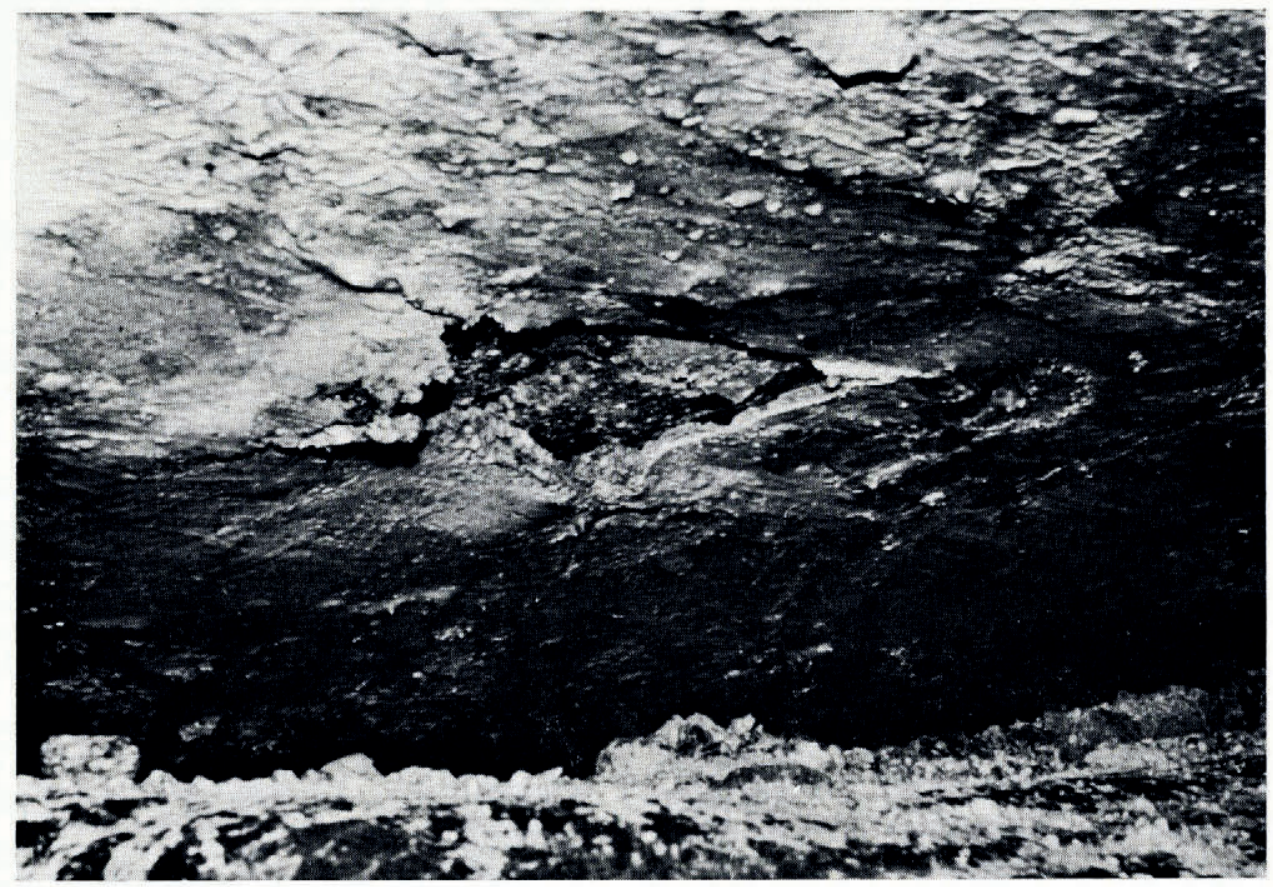

Fig. I. The ceiling of the subglacial cavity studied showing the plastered mud layer. Its frozen state is apparent thanks to a detached fragment visible in the centre of the picture. The glacier-bedrock contact is at the lower part.

(I) samples of water in contact with the mud layer corresponding to the situation before the forcing, and

(2) samples of ice accretions and water held at their surface corresponding to the situation after the forcing.

Many precautions were taken in order to reduce the contribution from contamination to the background noise level of the instrument, and to control chemical changes caused by the melting of the samples. Sampling procedure and sample treatment have been described previously in this fournal (Souchez and others, 1973).

Furthermore, determination of the adsorbed cations held on the surface of the fine particles (diameter inferior to $50 \mu \mathrm{m}$ ) of the mud layer has been done by the classical ammonium acetate method (Jackson, I958, p. 84). We assume that the cations exchanged by this method are those present in the diffuse layer existing between the negatively charged mineral surfaces and the external solution. In this diffuse layer, cations are much more numerous than anions because of the negative charges of the mineral surfaces. Together with such a mineral surface, the diffuse layer forms an electrical double layer (also called a Gouy layer).

\section{Results AND COMments}

Table I gives the mean and extreme values of the concentrations in $\mathrm{Na}, \mathrm{K}, \mathrm{Ca}$, and $\mathrm{Mg}$ of the samples. The ratios $(\mathrm{Na}+\mathrm{K}) /(\mathrm{Ca}+\mathrm{Mg}), \mathrm{Na} / \mathrm{K}$ and $\mathrm{Ca} / \mathrm{Mg}$ are also included.

A lower $(\mathrm{Na}+\mathrm{K}) /(\mathrm{Ca}+\mathrm{Mg})$, a lower $\mathrm{Na} / \mathrm{K}$, and a higher $\mathrm{Ca} / \mathrm{Mg}$ ratio can be observed in the Gouy layer of the mud than in the water in contact corresponding to the situation before the forcing. This is to be explained by selective adsorption governed by the ionic charge of the cations and their hydrated radii. The order of replaceability of the major 
cations has been established as follows: $\mathrm{Na}^{+}<\mathrm{K}^{+}<\mathrm{Mg}^{++}<\mathrm{Ca}^{++}$(Carroll, I959). The variations of the above-defined ratios between the Gouy layers of the mud and the water in contact are consistent with this order. This supposedly indicates that an equilibrium has been reached before the passage through the mud layer.

Table I. Concentrations of $\mathrm{Na}, \mathrm{K}$, Ca and $\mathrm{Mg}$ in the samples collected at the base of the glacier

\begin{tabular}{|c|c|c|c|c|c|c|c|c|c|}
\hline \multirow[t]{2}{*}{$\begin{array}{c}\text { Ionic species } \\
\text { or ratio }\end{array}$} & \multicolumn{3}{|c|}{$\begin{array}{c}\text { Water in contact with } \\
\text { the mud layer } \\
\mu \mathrm{eq} / 1 \\
\text { (17 samples) }\end{array}$} & \multicolumn{3}{|c|}{$\begin{array}{c}\text { Ice accretions and water } \\
\text { held at their surface } \\
\text { u.eq/1 } \\
\text { (9 samples) }\end{array}$} & \multicolumn{3}{|c|}{$\begin{array}{l}\text { Adsorbed cations on } \\
\text { the mud layer particles* } \\
\text { meq/I oo g dry mud } \\
\text { (8 samples) }\end{array}$} \\
\hline & mean & $\min$. & $\max$ & mean & $\min$. & $\max$. & mean & $\min$. & $\max$. \\
\hline $\mathrm{Na}$ & 71.6 & 28.3 & I 39.2 & 55.8 & 34.8 & 8o.o & 0.12 & o. 10 & 0.15 \\
\hline K & 176.4 & 61.4 & 296.6 & 58.7 & $35 \cdot 3$ & 8 г.8 & 0.44 & $0.3^{8}$ & $0.5^{1}$ \\
\hline $\mathrm{Ca}$ & 460.0 & $249 \cdot 5$ & 774.4 & 38.9 & 6.5 & $64 \cdot 4$ & 2.77 & 1. .88 & 3.57 \\
\hline $\mathrm{Mg}$ & 50.0 & $17 \cdot 3$ & 95.4 & 17.6 & 9. I & 32.9 & 0.18 & o. 14 & 0.23 \\
\hline $\mathrm{Na}+\mathrm{K}+\mathrm{Ca}+\mathrm{Mg}$ & 758.0 & 371.5 & I 263.7 & 171.0 & 89.7 & 242.2 & $3 \cdot 5^{2}$ & 2.53 & 4.23 \\
\hline$(\mathrm{Na}+\mathrm{K}) /(\mathrm{Ca}+\mathrm{Mg})$ & $0.5^{\circ}$ & 0.21 & 0.90 & 2.35 & 1.50 & 4.59 & 0.19 & o.13 & 0.26 \\
\hline $\mathrm{Na} / \mathrm{K}$ & $0.4^{\mathrm{I}}$ & 0.23 & $0.6 \mathrm{I}$ & $0.9^{6}$ & $0.8 \mathrm{I}$ & I. 12 & 0.27 & 0.23 & 0.33 \\
\hline $\mathrm{Ca} / \mathrm{Mg}$ & 10.02 & 6.49 & I 5.83 & 2.37 & 0.49 & $5.5 \mathrm{I}$ & 15.17 & $9.6 \mathrm{I}$ & 20.80 \\
\hline
\end{tabular}

* These values are different from those previously quoted (Souchez and others, 1973) since the whole mud layer has been considered here instead of the fine particles in contact with the ice accretions.

A comparison of the results between the samples of ice accretions and water held at their surface (a) and the samples of water in contact with the mud layer (b) leads to the following significant features:

(I) a lower content in the four cations for (a) than for (b) showing a desalinating effect during the forcing;

(2) a higher $(\mathrm{Na}+\mathrm{K}) /(\mathrm{Ca}+\mathrm{Mg})$ ratio for (a) than for (b) indicating a monovalentdivalent cation species separation;

(3) a higher $\mathrm{Na} / \mathrm{K}$ and a lower $\mathrm{Ca} / \mathrm{Mg}$ ratio for (a) than for (b) indicating sorting effects between the alkalies as well as between the alkaline earths.

These characteristics show that the frozen mud layer plastered at the base of the glacier may be considered as an ion-exchanger membrane causing electrolyte filtration and relative retardation of cations (Helfferich, 1962).

These membrane properties are explained by the peculiar electrochemical situation in the pores of the mud layer. The water flows in the form of thin films in which the ion concentration distribution is determined by the overlap of adjoining double layers. This distribution would also be approximately true in thin films of water adsorbed on single solid surfaces with air on the other side of the film (Kemper, I96o). In these situations, the concentration of the anions becomes very low (Donnan exclusion). Forcing the water through the membrane builds up a counteracting streaming potential which accelerates the anions and slows down the cations. In the case of strong Donnan exclusion, electrolyte transfer across the membrane is weak, since the anions are scarcely admitted to the membrane in spite of the streaming potential and, because of the requirements of electroneutrality, the cations are more and more slackened. This electrolyte filtration effect is selective, i.e. the passage rates through the membrane are different for different cation species. Their relative passage rates will depend on the resultant of all the forces affecting their selective adsorption and their selective transport (Kharaka and Berry, 1973):

(I) The forces of attraction between the cations and the electrical sites on the surface of the particles. In the electrolyte filtration process, increased strength of bonding of a cation will lead, everything else being equal, to its reduction in the effluent solution. 
For example, divalent cations in the diffuse layer tend to be closer to the walls of the pores and, consequently, the average divalent cation is not carried down-stream as fast as the average monovalent cation (Kemper and others, 1970).

(2) The forces of repulsion between the cations and the streaming potential, which mainly depend on the ionic potential (charge/radius) of the hydrated cations. The cation with the higher ionic potential has to overcome the larger repulsive force and thus is the most retarded. As for the preceding factor, the relative retardation sequence is $\mathrm{Na}<\mathrm{K}<\mathrm{Mg}<\mathrm{Ca}$.

(3) The dynamic force exerted on the cation by the flowing water, which is a direct function of its hydrated radius. The retardation sequence due to this factor is thus: $\mathrm{Mg}<\mathrm{Ca}<\mathrm{Na}<\mathrm{K}$.

Experimental work (Kemper and others, 1970) and field investigations (Berry, I969; Kharaka and Berry, 1973) indicate that with a low hydraulic pressure gradient, such as the one existing across the frozen mud layer at the base of the Glacier d'Argentière, the role of the dynamic force exerted by the flowing water can be neglected in comparison with the others, so that the relative retardation sequence to be considered is $\mathrm{Na}<\mathrm{K}<\mathrm{Mg}<\mathrm{Ca}$. This retardation sequence leads to a higher $(\mathrm{Na}+\mathrm{K}) /(\mathrm{Ca}+\mathrm{Mg})$ ratio, a higher $\mathrm{Na} / \mathrm{K}$ ratio, and a lower $\mathrm{Ca} / \mathrm{Mg}$ ratio for the effluent solution, which is the case at the base of the Glacier d'Argentière.

Now we must ask whether the calculated reduction of cationic content between the ice accretions and the water held at their surface and the water in contact with the mud layer is compatible with the model outlined above. The efficiency $E$ of a membrane is defined as:

$$
E=\left[\mathrm{I}-\frac{\text { effluent concentration }}{\text { inflow concentration }}\right] \times 100 \% \text {. }
$$

The efficiency of the mud layer for the four major cations considered as a whole is thus $77 \%$. A lot of experimental work has been done to determine the efficiency of a clay membrane for solutions of various ionic strengths. However these experiments differ considerably from the situation described at the base of the Glacier d'Argentière because of the much higher pressure used. Nevertheless, Kemper (1960) uses a NaCl solution under ro atmospheres, which is approximately the hydrostatic pressure at the base of the glacier, and gives the following values: $E=3 \%$ for a $\mathrm{I} \mathrm{N}$ solution, $E=10 \%$ for a $0 . \mathrm{I} \mathrm{N}$ solution and $E=32 \%$ for a 0.0 I $\mathrm{N}$ solution. The same author indicates that the efficiency increases considerably with solutions of lower salinity. In the case studied here, the normality of the inflow solution for each cation considered is below $0.0005 \mathrm{~N}$. Thus an efficiency of $77 \%$ for such a dilute inflow solution is not in conflict with these experiments. Now, if we determine the membrane efficiency for each cation separately, we get the following figures: $23 \%$ for $\mathrm{Na}, 67 \%$ for $\mathrm{K}$, $65 \%$ for $\mathrm{Mg}$, and $92 \%$ for $\mathrm{Ca}$. This is in agreement with the relative retardation sequence quoted above except for $\mathrm{Mg}$; the efficiency for this element is here slightly lower than for $\mathrm{K}$. However the significance of such a slight difference $(2 \%)$ is questionable in view of the limited number of ice accretion samples which have been considered as valid after treatment (particle content of less than $0.5 \mathrm{~g} \mathrm{l}^{-1}$ ).

The grain-size distribution of the mud layer indicates that it consists of sand with about I0 $\%$ silt and $2 \%$ clay. The clay fraction is mainly illite as determined by X-ray diffraction. These characteristics are somewhat different from those of the electrolyte filtration experiments where a clay membrane is used. However, the mud layer is frozen at a temperature close to the melting point, so the large pores are filled with ice and unfrozen water exists partly at the interface between the mineral grains and ice and partly in crevices and capillaries where the radius of curvature is sufficiently small (Anderson, i 967 ). In such a situation, the ions must migrate through thin films of unfrozen water which are continuous through the frozen mud (Hoekstra and Chamberlain, ig64). 
By comparing the situation before and after forcing across the mud layer, the chemical sorting effect postulated in Souchez and others (r973) is established. In comparison with this earlier paper, the reader will notice a difference in content of cations adsorbed on the particles in the mud layer. This is due to the fact that the whole mud layer has been sampled here instead of only the particles in contact with the ice accretions. So, the values reported in Table I of this paper are considered as more relevant.

\section{Conclusion}

A chemical sorting effect takes place at the base of the Glacier d'Argentière under the influence of a mud layer which acts as an ion-exchange membrane.

This effect is likely to occur in other glaciological situations. The basal part of an alpine glacier sometimes consists of stratified ice, i.e. interbedded layers of ice and frozen mud. Chemical analysis of this stratified ice may shed some light on its origin and so on the processes operating in the basal part of a glacier. The chemical composition of stratified ice is likely to be influenced by such a chemical sorting effect.

MS. received 3 June 1974 and in revised form 29 October 1974

\section{REFERENGES}

Anderson, D. M. 1967 . The interface between ice and silicate surfaces. Fournal of Colloid and Interface Science, Vol. 25, No. 2, p. $174-9$ 1.

Berry, F. A. F. 1969 . Relative factors influencing membrane filtration effects in geologic environments. Chemical Geology, Vol. 4, Nos. 1-2, p. 295-301.

Carroll, D. 1959. Ion exchange in clays and other minerals. Bulletin of the Geological Society of America, Vol. 70, No. 6 , p. $749^{-79}$.

Helfferich, F. I962. Ion exchange. New York, McGraw-Hill.

Hoekstra, P., and Chamberlain, E. I 964 . Electro-osmosis in frozen soil. Nature, Vol. 203, No. 4952 , p. $1406-07$.

Jackson, M. L. 1958. Soil chemical analysis. Englewood Cliffs, Prentice-Hall Inc.

Kemper, W. D. 1960. Water and ion movement in thin films as influenced by the electrostatic charge and diffuse layer of cations associated with clay mineral surfaces. Soil Science Society of America. Proceedings, Vol. 24, p. $10-16$.

Kemper, W. D., and others. 1970. Separation of adsorbed cation species as water flows through clays, by W. D. Kemper, I. D. Sills and L. A. Aylmore. Soil Science Society of America. Proceedings, Vol. 34, p. 946-48.

Kharaka, Y. K., and Berry, F. A. F. 1973. Simultaneous flow of water and solutes through geological membranes-I. Experimental investigation. Geochimica et Cosmochimica Acta, Vol. 37, No. 12, p. $2577-603$.

Souchez, R. A., and others. 1973. Refreezing of interstitial water in a subglacial cavity of an alpine glacier as indicated by the chemical composition of ice, by R. A. Souchez, R. D. Lorrain and M. M. Lemmens. Fournal of Glaciology, Vol. 12, No. 66, p. 453-59. 